\title{
Fluctuations in the momentum of growth within the capitalist epoch
}

\author{
Angus Maddison
}

Received: 21 August 2006/ Accepted: 15 October 2006/Published online: 6 February 2007

(C) Springer-Verlag 2007

\begin{abstract}
This paper reviews the history of cyclical and long wave analysis and examines the evidence on changes in the momentum of economic growth in 16 advanced capitalist countries from 1820 to 2001. It assesses the work of the main Business Cycle Research Institutes in Western Europe the USA and Russia, as well as that of Kondratieff, Kuznets, Schumpeter, Abramovitz and the long-wave revivalists-Rostow, Mandel and Mensch. It concludes that the existence of regular long-term rhythms in capitalist development is not proven, but distinguishes major changes in the momentum of growth due to disturbances of an ad hoc character. The role of system shocks and historical accidents is important but the role of policy error and success is also emphasised. It identifies five major phases of capitalist development since 1820 .
\end{abstract}

Keywords Business cycles $\cdot$ Long waves $\cdot$ Economic growth

Jel Classification $\quad \mathrm{C} 82 \cdot \mathrm{E} 01 \cdot \mathrm{N} 10$

\footnotetext{
This is a modified and updated version of chapter 4 in Maddison, Dynamic Forces in Capitalist Development, OUP, 1991. It incorporates substantial improvements in the coverage of historical statistics back to 1820, and updates my earlier analysis from 1989 to 2001. There is also extensive new analytical material on long waves: (a) Vincent Barnett's (1998) exciting and carefully researched biography of Kondratieff provides a comprehensive assessment of his publications and professional activity; (b) four volumes by Makasheva et al. (1998) contain new translations of a substantial part of Kondratieff's work; (c) an exhaustive analysis of these issues in the compendium volumes of Christopher Freeman (1996) and Louçã and Reijnders (1999); (d) the impressive survey of the whole field by Freeman and Louçã (2001).
}

A. Maddison ( $\square)$

Faculty of Economics, University of Groningen, 9700 AH Groningen, The Netherlands e-mail: angus.maddison@wanadoo.fr 
Capitalist development has not been smooth. There have been important changes of momentum which are worthy of study, definition, and causal interpretation. There have also been shorter-term fluctuations, usually called business cycles. My primary interest is not in these, but in major changes in the dynamics of growth which involved basic changes in the institutional-policy mix and were usually initiated by some sort of 'system shock' which upset the international economic order.

Before presenting my own diagnosis, it is useful to trace the history of cyclical and wave analysis. In the past there has been extensive discussion of long waves. Interest revived in the 1970s after a period when the long-wave hypothesis was regarded as quaint and the business cycle obsolete.

\section{Analysis of business cycles}

Cyclical analysis started in 1856 with Clement Juglar (1819-1905) and 1862 with Jevons (1835-1882). Both emphasized periodicity in economic activity whereas most earlier writers interpreted interruptions to growth as random financial crises. Jevons work was largely concentrated on English experience and had an idiosyncratic emphasis on the influence of sun-spots (1). Juglar's analysis was comparative. He concluded that cycles were roughly synchronous in France, the UK, and USA. The evidence he assembled related mainly to monetary phenomena-expansions or contractions in central bank activity, rates of interest, prices of key commodities, etc., plus narrative 'business annals'. It is frequently asserted that Juglar found cycles of a characteristic length of 9 years, but this is not in fact true. His cycles for France averaged 7 years with a range from 3 to 18 years, and for the UK 6 years with a range from 2 to 10 years.

For several decades the quantitative indicators available to cyclical analysts were similar to those used by Juglar, though they were later augmented to include price indices, data on output and foreign trade. A more sophisticated causal analysis (under-consumptionist) was also developed by the Russian economist Mikhail Tugan-Baranowsky (1894, 1865-1919) in 1894 in his analysis of cycles in the UK.

In the 1920s, institutes were set up in several countries to measure and interpret variations in current economic activity, in historical perspective. These included the Conjuncture Institute in Moscow and the National Bureau of Economic Research (NBER) in New York, both set up in 1920. The London and Cambridge Economic Service started its Monthly Bulletin in 1923. In 1925, Ernst Wagemann, the President of the German Statistical Office, set up an officially financed Institut fur Konjunkturforschung in Berlin, with a staff of 50, to brief decision-makers in the public and private sectors with an up-to-date analysis of the economic situation (see Tooze 1999). In 1933 it became the Deutsches Institut für Wirtschaftsforschung. The Institute of Statistics in the Sorbonne in Paris, the Institutes of Statistics in the Universities of Rome and Padua presided by Corrado Gini, and the League of 
Nations Committee of Experts on Economic Barometers started work in 1926. The Osterreichisches Institut fur Konjuncturforschung, directed by Friedrich von Hayek, started in Vienna in 1927 (see Mitchell 1927, pp 201-202). At this time, most of these countries did not have national accounts (except Germany, where they were initiated in 1929 and the USA from 1934), so their basic analytical tools were not macro-measures of output, expenditure and income but miscellaneous indicators of prices, financial transactions, commercial activity, output of various agricultural, mining and manufacturing products. They concentrated on business activity and generally ignored the role of government. The heterogeneity of their indicators was a substantial problem in measuring cross-country synchronicity of business cycle movements.

The ultimate refinement in this type of business cycle analysis was the massive effort of the NBER, under the successive leadership of Wesley Mitchell (1874-1948), and Arthur Burns (1904-1987). The first phase of their research was preparation (a) of a huge databank of statistical indicators and charts on production, construction, transport and communication, wholesale, retail and foreign trade, wages and employment, currency, banking and financial transactions (see Mitchell 1927), and (b) narrative chronologies of past cycles (business annals). The annals were compiled by Willard Thorp (1926), in liaison with associates in other countries, including von Hayek, Aftalion, R. Kuczinski, and Kondratieff; they provided a cyclical periodisation for 17 countries; for the UK and USA back to 1790, for other countries to the mid-nineteenth century. With this material, NBER developed a series of 'reference cycles' for four countries (France, Germany, Great Britain, and the USA) based mainly on monthly quantitative data, which started in 1854 for the last two countries, in 1865 for France, and 1879 for Germany. The number of monthly or quarterly series for the USA was 19 for 1860 rising to 811 in 1942 (plus 161 annual indicators). The monthly and quarterly series were seasonally adjusted. For the three European countries the number of indicators was much smaller. The NBER derived its 'reference cycles' by plotting most of the information on charts in de-seasonalized form, and, by iterative procedures of inspection, identifying the turning points of cycles by the size of clusters of roughly concurrent fluctuations (Burns and Mitchell 1947, pp 20:78-79, and 82). Thus its central concept of economic activity was a fuzzy cocktail rather than a clearly defined measure of aggregate economic activity.

The main purpose was to develop sensitive warning indicators of turning points in business activity. These were classified as leading, coincident, or lagging. The reference cycle became part of the official statistical armoury of the USA for forecasting purposes, though it is now supplemented by the more sophisticated econometric models of aggregate activity (quarterly GDP). For the period 1857 to 1978 the NBER discerned 28 successive peak-to-trough movements for the United States, i.e. a recession on average every 4 years, with a variation in their incidence from two-and-a-half to nine-and-a-half years. For other countries the average duration was found to be longer: 53 months for France, 62 for the UK and 64 for Germany for prewar years. The NBER cycles were not adjusted to eliminate trend, so they were not 
measures of oscillation in economic activity. They registered recessions only when there was an absolute fall in the relevant indicators (2).

The NBER technique of using monthly and rather volatile series picked up more cycles than a GDP index based on annual data, and the 'reference cycles' that did correspond with GDP movements did not always have exactly the same dates (3). The NBER approach is a useful tool in interpreting quantitative economic history, but a major problem is that it yields no satisfactory measure of the amplitude of fluctuations because of the difficulty of producing a meaningful summary measure from such heterogeneous data. Thus one cannot use the reference cycle itself to distinguish major and minor cycles, in the same way that one can with simpler measures of industrial output or GDP.

Arthur Burns (1934), Production Trends in the United States since 1870 was an attempt to look at longer term 'trend cycles', based on annual movement (1870-1929) of commodity output indicators for 90 agricultural, mining and industrial items and 14 for transport and communications. It analysed patterns of growth and retardation for individual industries, but made no attempt to measure their aggregate movement.

Although the bulk of NBER research in the 1920s was concentrated on business cycles, there was also a feeble effort to measure national income of the USA. Two studies were published in 1921, followed by Wilford King's unimpressive National Income and its Purchasing Power in 1930, which contained no aggregate estimate nor any concept of what such an aggregate would be. In 1930 Mitchell asked Simon Kuznets to take over the work on national income. Kuznets migrated to the USA in 1922, after doing his undergraduate studies in Kharkov. He did his Columbia Ph.D. thesis on cyles under Mitchell in 1926 and worked in the Bureau in 1927-1929 on his post-doctoral monograph Secular Movements in Production and Prices (1930). It resembled other work in the Bureau in type of indicator, but Kuznets used only annual data, had somewhat wider country coverage, much more ambitious decomposition of time series, explored fluctuations over periods distinctly longer than business cycles, and his analytical approach was influenced by the Russian tradition. From 1930 onwards his professional interests were transformed. He blazed a new trail which he followed for the rest of his life, developing comprehensive measures of aggregate activity and economic growth, first for the United States, and then the rest of the world. He lost interest in the fuzzy cocktail of indicators that continued to be Burns'delight, though he continued his close association with the NBER, and was successful in persuading it to undertake important studies on economic growth which buttressed his own work (4).

\section{Long-wave analysis}

Although there was some discussion of the Great Depression (in prices) in the last quarter of the nineteenth century, the idea of recurrent long waves 
in capitalist development did not arouse much interest until after the First World War, i.e., about 50 years later than cycle analysis, when the rhythm of development had been very dramatically broken. The main long-wave analysts were van Gelderen (1913), Kondratieff (1922, 1926, 1992, 1998), Kuznets (1926, 1961, 1965), and Schumpeter. All drew heavily on cyclical indicators to test their ideas quantitatively.

\section{Van Gelderen (1891-1940)}

Jacob van Gelderen was not the first to distinguish long waves, but he was the first to measure them (5). He was a statistican in the municipality of Amsterdam, later (1919-1933) chief statistician in Indonesia, and worked thereafter in the Dutch Ministry of Colonies. As a civil servant, he wrote under a pseudonym (Fedder, his mother's maiden name). He was active in the Jewish labour movement (Poale Zion) and his article on long waves was published in 1913 in three successive issues of the Dutch SocialDemocratic party's journal (De Nieuwe Tijd). This had been founded in 1896, on the the model of Die Neue Zeit, the organ of the German SDP founded in 1883 by Karl Kautsky. Both journals had been vehicles for Marxist discussion of the dynamics and prospects of capitalism-crises, overproduction, likelihood of breakdown, and for reviews of books on stages of capitalist development by Werner Sombart in 1902, and Rudolf Hilferding in 1910. Van Gelderen mustered a good deal of statistical material on wholesale price movements in Austria-Hungary, Belgium, Canada England, France, Germany and the USA, foreign trade and gold production, stock market activity and interest rates. Without any decomposition of his time series, he concluded by inspecting his evidence in graphical form, that there had been a long cycle of 45 years between 1850 and 1895. There were two phases-expansion and contraction. The former he called a "spring tide" (1850-1873), when prices rose. In 1873-1895 there was an "ebb tide" when prices fell. He discerned a second long wave beginning in 1895 . He demonstrated his waves most clearly by a technique later adopted by Kuznets. He smoothed out shorter 10-year cycles in the period 1845-1911, by presenting averages for overlapping decades ( $p$ 269) of the Sauerbeck price index. He argued that movements of this kind were inherent characteristics of the capitalist system associated with surges and recessions in capital formation, expansions of the European capitalist orbit to include north America and Australasia, fluctuations in gold production, etc. However, he did not suggest that the system was threatened with breakdown. One gets the impression that he felt these waves to be more or less ineluctable and innocuous. Van Gelderen and his family committed suicide in May 1940, when the Nazi army invaded the Netherlands. 


\section{Kondratieff (1892-1938)}

Nikolai Kondratieff was a Russian economist (a pupil of Tugan-Baranowsky), who worked on agrarian problems and business cycles. His long wave analysis was much more sophisticated than van Gelderen's. He was very briefly vice minister of food supply in 1917, in the Kerensky government preceding the October revolution. Thereafter he taught in the Agricultural Academy, worked on agrarian reform with Chayanov and Makarov and was the founder and director (1920-1928) of the Business Cycle Research Institute in Moscow. He was also a high-level policy advisor to the Ministry of Agriculture and the Ministry of Finance in the 1920s. The Institute's large staff (50 people) included distinguished economists and statisticians: Eugen Slutsky, the expert on mathematical decomposition of time series, A. A. Konus, who did pioneering work on consumer price indices and Albert Vainstein, who survived and moved on from business indicators to macromeasurement. Its job was to monitor the economic situation in the USSR and the major capitalist economies and to make economic forecasts. It was financed from the budget of the Ministry (People's Commissariat) of Finance.

Several of Kondratieff's articles were published in translation and he traveled abroad to establish contact with kindred researchers. From early June 1924, accompanied by his wife, he spent a month in Berlin, 10 weeks in England (Cambridge, Oxford and London) and 3 months in the USA on an official mission for the Ministry of Agriculture to gather information on the international competition which Soviet agriculture faced. His most intensive agricultural investigations took place in the USA where he had many discussions with public officials in Washington from the Secretary of Agriculture, Henry Wallace, downwards. He also took the opportunity to meet economists with kindred interests. In England he met Keynes, visited the London School of Economics and the Royal Statistical Society. He met Irving Fisher at a meeting of the American Economic Association in Chicago. He participated in a conference of agronomists in Cornell University in Ithaca, where he met Kuznets' older brother, Solomon, who was teaching there. His most extensive discussions and subsequent correspondence related to his work on cycles were with Wesley Mitchell in New York. Mitchell was briefed on Kondratieff's work by Simon Kuznets who was his Ph. D. student at the time. It is not clear whether Kuznets talked to Kondratieff in New York, but they probably met in Cornell (6).

In the 1920s, there was freedom to exchange opinions and criticise official policy in the USSR which disappeared in 1928. Within the Institute, Kondratieff submitted his work to detailed comment by his colleagues. The report of a 1926 discussion reads like a session reported nowadays in Brookings Papers on Economic Activity. Kondratieff (1925b) presented a 67 page paper (a revision of his first long wave paper of Kondratieff 1925a). It was subjected to an 81 pages critique by D. I. Oparin, 22 pages of comment by seven other colleagues, a 40 pages reply by Kondratieff, a 17 pages reply from Oparin, and 
46 pages of tables and notes. (see Kondratieff and Oparin 1928 and its full translation in Makasheva et al. 1998, vol. 1).

Kondratieff distinguished three kinds of cycle: long ones of 50-year-duration, middle ones of 7 to 10 years, and short ones of 3 to 4 years. He measured the long cycles by a double decomposition of time series-eliminating the trend and showing a secondary movement-a 9-year moving average of the deviations from trend. Nine-year averaging was enough to remove the influence of the two shorter types of cycle. His analysis covered the period 1770 to the 1920s and the duration of his long cycles ranged from 40 to 60 years. Kondratieff also adjusted his series to eliminate the population component, in which some Kuznetsians (Brinley Thomas and Richard Easterlin) found the best evidence for their own long-wave analysis.

Kondratieff's waves were most clearly demonstrated by long-term movements in wholesale prices, though some of the long-term oscillation was obviously attributable to wars (e.g., the peaks in the Napoleonic wars and 1914-1920). He analysed wholesale price developments for France, the UK, and the USA, and it is not surprising that in these relatively open economies he found price trends to be similar. After he adjusted to eliminate the effect of exchange rate changes, the individual country series gained greater synchronicity. On this basis Kondratieff claimed his waves to be an international phenomenon.

Most of Kondratieff's other indicators contained a strong price element, because they were expressed in current values: e.g., wages, interest rates, the value of foreign trade, and bank deposits. Not surprisingly, the price component of these value series moved in a similar way as the general price indices (7). The only physical series were those relating to per capita coal production in England, coal consumption in France, pig iron and lead production in England.

Kondratieff concluded tentatively that, on the basis of available data, it was very probable that there had been three long cycles in economic life (a rather vague term, but one that is clearly intended to include output as well as price movements). His chronology referred not to particular years but to spans, and he distinguished only two phases, the rise and fall, in each wave. He did not discuss the amplitudes of these waves, which varied between series. His dating is shown in Table 1.

There are several problems with Kondratieff's approach. The first is his failure to establish that long waves exist as more than a monetary phenomenon. He failed to show the existence of broad movements in the volume of output that even remotely correspond to our present measures of aggregate

Table 1 Kondratieff's long-wave chronology

\begin{tabular}{lll}
\hline & Rise & Decline \\
\hline First long wave & 1780 s-1790s to $1810-1817$ & $1810-1817$ to $1844-1851$ \\
Second long wave & $1844-1851$ to $1870-1875$ & $1870-1875$ to $1890-1896$ \\
Third long wave & $1890-1896$ to $1914-1920$ & $1914-1920$ to ? \\
\hline
\end{tabular}


economic activity. The second problem was that he eliminated the trend and discarded it as if it were irrelevant to the discussion.

Between 1820 and 2001, British GDP rose 33-fold, and American by 635fold. This fact is left out when the time series are decomposed in Kondratieff fashion for wave analysis, but such very different trends transform the nature and operational significance of any long waves that may be discerned. The third problem is that double decomposition of time series to eliminate trend and smooth out cycles blurs the impact of major historical events. Thus, Kondratieff's chronology pays no attention to the impact of the First World War, and later long-wave analysts tend to brush off the catastrophic 19291933 recession and the Second World War as well. Finally, Kondratieff threw out some hints on long-cycle causality, but did not adequately explain why capitalist development should involve long waves as a systematic phenomenon.

There is no doubt that Kondratieff's contribution to long-wave analysis was fundamental. He formulated the three-cycle schema adopted by Schumpeter, and his statistical technique was very similar to that Kuznets used to distinguish 'secondary secular movements'. Furthermore, he pointed to the likelihood of poor terms of trade for agriculture in periods of decelerated development-a point given major stress later by Walt Rostow and Arthur Lewis (see Kondratieff 1928b).

Outside his own Institute, Kondratieff was heavily cricised because his long cycle analysis seemed to conflict with the more fundamental Marxist expectation of the ultimate breakdown of capitalism (see Garvy 1943). He was dismissed from the Institute in 1928 "for introducing ideology alien to Soviet policy into his work'. The Institute was merged with the Central Statistical Office in 1928 and abolished in 1929. Kondratieff was arrested and interrogated in 1930, sentenced to 8 years in prison in 1932 and executed after a second trial in 1938. His alleged counter-revolutionary crimes were not attributable to his long-cycle analysis, but his public opposition to the Stalinist collectivization of agriculture (in which he was associated with his friend Chayanov, who was also executed). Kondratieff's wife and daughter preserved his unpublished work and pressed for his rehabilitation. During Khruschev's 1963 thaw the 1938 death sentence was repealed, and in 1987, with Gorbachev's glasnost, the 1932 sentence was also repealed. Menshikov (1984) in 1984 published the first article on Kondrieff's work in the USSR since the 1920s, and in the 1990s, Kondratieff's work was republished in Russia (see Makasheva, p xxxiii).

\section{Kuznets (1901-1985)}

Chronologically, the next development in the long-swing literature was Simon Kuznets' analysis of 'secondary secular movements' published in 1930. Kuznets was educated in Kharkov and worked in the Ukrainian Statistical Office before emigrating to New York in 1922. He was already a sophisticated 
and well-trained economist. His research interest centred on business cycles and long waves in economic activity. At that time, analysis of this field was more sophisticated in Russia than in the United States. Tugan-Baranowsky and Eugen Slutsky were both teaching in the Ukraine when Kuznets was a student and he was very familiar with Kondratieff's work on long waves. His basic technique for identifying long waves was similar to that of Kondratieff, i.e. it involved elimination of the trend from the basic annual data, and used a nine-year moving average to smooth the deviations from trend. The latter he called secondary secular variations. However, Kuznets made a special point of not eliminating population movements, his technique for eliminating trend was different from that of Kondratieff, and his conclusions were also different.

Kuznets' evidence was more detailed, involving careful analysis of 59 series, most of which represented annual movements in physical output and the relevant price variance for particular commodities. He presented 23 indicators for the USA, of which 16 were commodities with both price and quantity data and six were financial indicators (including the general price index). For the UK he had nine indicators, France and Germany eight each, Belgium five, Canada and Japan two each, Australia and Argentina one each. He did not claim that the individual indicators could be added to provide a meaningful picture of aggregate economic activity, and he did not use aggregative sector indicators for agriculture or manufacturing that were available when he wrote.

His major conclusions were: (a) that "secondary secular variations in production are in most cases similar to those in prices, the latter following a rather general course in agreement with the well-known historical periods of the rise and fall in the general price level" ( $p$ 197); (b) he found a much shorter periodicity than Kondratieff, "about 22 years as the duration of a complete swing for production and 23 years for prices" (p 206); (c) most fundamentally, he did not think there was enough evidence to conclude that these secondary secular variations were systematic. They were "rather specific, historical occurrences" (p 258) and there was "an absence of factors that would explain the periodicity" ( $p$ 264). Kuznets did not attempt to cluster his individual series to present a global chronology of long waves in economic life, nor did he analyse the degree of synchronization of the series (8).

From 1930 onwards, Kuznets dropped his work on cycles and the indicator approach, moved on to growth analysis and aggregate measures of economic activity. He did fundamental definitional work on the scope and composition of aggregate GDP measurement and produced historical estimates of US economic development that conformed to his criteria. Thus he made it possible to analyse long-term movements in economic life on a much more satisfactory conceptual basis than the cocktail approach that he and virtually all cyclical analysts had previously been forced to use. Furthermore, Kuznets successfully stimulated and inspired replication of his work by scholars in many other countries. This aggregate accounting approach had some drawbacks for cyclical analysis, before GDP estimates were available on a quarterly basis, but it revolutionized the study of long-term growth and greatly facilitated the testing of long-wave analysis. 
From time to time after 1930 Kuznets returned to long-swing analysis in a rather tentative way. Unlike his disciples, he himself never called them 'cycles', as the word implied greater certainty about such phenomena and their periodicity than Kuznets conceded. In Kuznets (1956, p 50) he showed an "internationally common chronology" of long swings for eight countries, applying a different analytic technique from that he used in 1930, and different indicators-decennial averages of population, GDP and GDP per capita. In Kuznets (1971, pp 43-50), a rewritten version of the 1956 paper, he was more cautious about synchronicity. His most affirmative position was in his 1958 essay on population growth, where he found the long-swing hypothesis plausible in relation to US population growth and to "population-sensitive" components of capital formation such as housing and railway construction (9).

\section{Abramovitz (1912-2000)}

Although Kuznets had abandoned long-swing analysis, he had several disciples with a continuing interest in what Arthur Lewis called 'Kuznets Cycles' (10). Moses Abramovitz made the most ambitious attempt to discern long swings in aggregate US economic activity and veered between more positive affirmation of long swings than Kuznets and outright recantation, in the sense that he did not find valid evidence for the phenomenon in the postwar period. His work in this field was almost entirely concerned with the US economy.

Abramovitz distinguished waves of acceleration and retardation in US growth with an average duration for the full swing of 14 years and a variance from 6 to 21 years, using NBER reference cycle indicators back to the 1820s. He used a cocktail of 29 indicators including GNP. He smoothed his series by a rather complicated procedure, designed to eliminate NBER reference cycles, before removing the trend. He found that the turning points of his different series "cluster in relatively narrow bands of years". He therefore produced a general chronology with nine swings between 1814 and 1939.

Even at his most affirmative, Abramovitz was basically cautious about the nature of long swings. Thus in 1959 he wrote: "It is not yet known whether they are the result of some stable mechanism inherent in the structure of the US economy, or whether they are set in motion by the episodic occurrence of wars, financial panics, or other unsystematic disturbances". In 1968 he concluded that Kuznets cycles were "a form of growth which belonged to a particular period in history" (1840-1914), and had disappeared thereafter. He was somewhat miffed by the fact that Kuznets showed little interest in his work on "Kuznets' cycles" (see Abramovitz 2000, p 111).

\section{Schumpeter (1883-1950)}

The most complex cycle system was propounded by Joseph Schumpeter. He incorporated Kondratieff long waves of 50 years, on each of which he 
superimposed 8 to 9-year 'Juglars'. Within each Juglar, he showed three 40month 'Kitchin' cycles (see Chart I in Schumpeter 1939, pp 213, and 1051). He said nothing about the amplitude of these cycles. Schumpeter insisted on the empirical regularity of his schema as if the basic facts about the three cycle components were well established, whereas there is great doubt about all three, as well as the legitimacy of his nomenclature. Kitchin's paltry contribution to the literature in 1923 was lean meat indeed compared with that of the NBER, and Juglar never claimed to have demonstrated the existence of an 8 to 9 -year rhythm. In fact, the NBER had already demonstrated rather wide variance in the length of cycles, so that there was little ground for distinguishing Juglars and Kitchins.

Schumpeter's treatment of statistical material was illustrative rather than analytic and was at times rather cavalier. In Schumpeter (1939) he used business annals of the type favoured by his former colleague Spiethoff (18731957), or by Tugan-Baranowsky, both of whom had an obvious influence on his views. He also used NBER type of statistical 'cocktail' material in pulse charts of industrial production, prices, interest rates, deposits, and currency circulation ( $\mathrm{p} 465)$. He made passing reference to national income analysis ( $p$ 561 ), but elsewhere referred to the concept of total output as a "meaningless heap" (p 484), national income as a "highly inconvenient composite" (p 561).

Schumpeter's long-wave chronology (see Table 2) was rather similar to that of Kondratieff (see Table 1), though he gave each a name and divided each wave into four phases rather than two (11).

Schumpeter's cycle analysis ran to 1,050 pages and was highly discursive. Judged on its statistical evidence alone, it would have been long discredited. Its power lies in the imaginative theory he supplied to explain long waves and the highly illuminating commentary on many aspects of German, British, and American economic history. He argued that each wave represented a major upsurge in innovation and entrepreneurial dynamism. Although writing in the late 1930s, he was remarkably sanguine about the long-run productive potential of capitalism. For him, depressions were a necessary part of the capitalist process. They were a period of creative destruction, during which old products, firms, and entrepreneurs were eliminated and new products were conceived. Schumpeter (1943, p 64) dismissed the 1929-1933 recession much too lightly "the depression that ran its course from the last quarter of 1929 to the third quarter of 1932 does not prove that a secular break has occurred in

Table 2 Schumpeter's long-wave chronology

\begin{tabular}{|c|c|c|c|}
\hline Prosperity & Recession & Depression & Revival \\
\hline \multicolumn{4}{|c|}{ Industrial revolution Kondratieff (cotton textiles, iron, and steam power) } \\
\hline $1787-1800$ & $1801-1813$ & $1814-1827$ & $1828-1842$ \\
\hline \multicolumn{4}{|c|}{ Bourgeois Kondratieff (railroadization) } \\
\hline $1843-1857$ & 1858-1869 & $1870-1885$ & $1886-1897$ \\
\hline \multicolumn{4}{|c|}{ Neomercantilist Kondratieff (electricity, automobiles, chemicals) } \\
\hline 1898-1911 & $1912-1925$ & 1925-1939 & $?$ \\
\hline
\end{tabular}


the propelling mechanism of capitalist production because depressions of such severity have repeatedly occurred-roughly once in every 55 years". He then quoted the 1873-1877 period as if it were a precedent for 1929-1933. Such a comparison was totally misleading. In the earlier period the peak-trough fall in US industrial production was $14.8 \%$; in the later one, $44.7 \%$ ! There was no earlier parallel to the 1929-1933 collapse either in amplitude or international incidence.

Like most long-wave analysts, Schumpeter gave primary stress to autonomous features of the capitalist process and said very little about the role of government in economic life. When he did mention government, it was usually to scorn its perversity-as in his attack on Roosevelt's New Deal-though he regarded government as pretty impotent. For him the driving force in economic life was entrepreneurship, which he regarded as having been taken over more or less completely by large firms. The emphasis on entrepreneurship was present in his earliest work on capitalist development written in 1911, and was obviously influenced by the ideas of Max Weber and Werner Sombart, which were popular at that time.

The main weaknesses of Schumpeter's long-wave theory (ignoring his failure to demonstrate their existence in the real world) were threefold: (a) he did not explain why innovation and entrepreneurial drive should come in regular waves rather than in a continuous but irregular stream, which seems a more plausible hypothesis for analysis concerned with the economy as a whole; (b) he made no distinction between the lead country and the others, but argued as if they were all operating on the same level of productivity and technological opportunity. Thus his waves of innovation were expected to affect all countries simultaneously; (c) he greatly exaggerated the scarcity of entrepreneurial ability and its importance as a factor of production.

Schumpeter extended his analysis of capitalist development further in 1943 in Capitalism, Socialism and Democracy. It was not concerned with long waves but with capitalist breakdown. This was paradoxical coming from an analyst who had such great faith in its robust character. However, his breakdown theory was sociopolitical rather than economic. He argued that there were four major forces destroying capitalism. In the first place, entrepreneurship was likely to be stifled by bureaucratization of management and decision-making in large firms. The second menace was the disincentive of progressive taxation and the increasing power of trade unions, which had already (he argued) retarded US recovery in the 1930s and were likely to become more stifling. The third threat came from the growing power of socialist ideas, and the fourth from the unpopularity of capitalism with intellectuals, who were continually engaged in denunciatory activities and harassments such as anti-trust suits.

Schumpeter's approach to long waves and the breakdown of capitalism contained bold hypotheses and unsettling paradoxes, which gained in impact through his emotional detachment. His view of capitalist development was fatalistic, and he wrote as if he were charting destiny. He disliked most of what was happening in the real world, but did not advocate policies to remedy the 
predicted catastrophe. In fact, one is never sure with Schumpeter whether he was putting forward a specific hypothesis because he seriously believed it or because it stimulated interest in his fundamentally dynamic and original conception of capitalist development.

\section{Long-wave revivalists}

The significant slowdown in the momentum of economic growth after 1973 revived the notion of long rhythms in economic life and a number of new longwave pundits emerged, most of them neo-Schumpeterians. Some were vulgarizers of past long-wave theories, which they invoked uncritically in support of a fashionable gloom about the future (12). Others deserve critical inspection, though I have not found much in their work to shake my scepticism about long waves as a systematic phenomenon affecting output.

\section{Rostow (1916-2003)}

Walt Rostow's interest in 'Kondratieff' movements was concentrated on swings in the terms of trade of primary producers against those selling industrial goods. From his viewpoint the 1951-1973 period was the 'downswing' of a fourth Kondratieff, and the OPEC-inspired price increases marked the upswing of a fifth Kondratieff. He produced 800 pages of empirical material to back his thesis, in welcome contrast to some of his earlier work. However, he complicated his argument by embedding his long waves in a loosely integrated framework that featured neo-Schumpeterian surges of innovation in leading sectors, demand changes as economies work themselves through a hierarchy of stages, and a reiteration of his earlier erroneous belief that there was a short, sharp take-off in Western countries which was staggered in time. Rostow (1978) placed great emphasis on a mishmash of sectoral and commodity indicators and had little time for broad aggregates such as GDP, which to my mind are the central indicators to be used in measuring acceleration or deceleration of growth.

\section{Mandel (1923-1995)}

Ernest Mandel was an erudite Belgian Marxist of Trotskyite persuasion. He asserted that there are long swings, roughly 50 years in length, caused by surges of new technology. In each swing there were two phases. In the first, profit rates rise as new technology is developed, and in the second they fall as technical possibilities are exhausted. The timing, like the causality, is similar to Schumpeter's. His first wave, from the 1780 s to 1847 was attributed to the 'industrial revolution'; the second, from 1847 s to the 1890 s, to a technological revolution dominated by 'machine production of steam motors'; the third, 
from the 1890 s to 1939 , to 'machine production of electric and combustion motors'; and the fourth, from 1940 to a future unspecified date, with machine production of electronic motors and atomic energy. He suggests that the first phase of the fourth wave ended in 1967 and that we were in the second phase at the time he was writing. Unlike other writers in this vein, he did not refer to the waves as 'Kondratieffs'. He considered Kondratieff unoriginal as compared with van Gelderen, for whose work he had exaggerated respect (13).

Mandel was mainly interested in theory and his empirical underpinning was very weak. He claimed ( $p$ 137) that 'economic historians are practically unanimous' in distinguishing expansions and recessions in the periods he used in his periodization, but the only justification he gave was an article by Hans Rosenberg (1943) published in 1943, which itself contained no empirical material and was written before quantitative economic history began. Mandel also presented estimates of world trade and industrial production indices for the UK, Germany, and the USA to buttress his argument. These were not deviations from detrended moving averages, but compound rates of growth between the years specified (which varied by type of indicator).

Table 3 shows Mandel's indicators for his second-wave downswing, which he called a period of 'pronounced depression', and for his third-wave upswing, which he characterised as a period of 'tempestuous increase in economic activity'. Mandel's statistical evidence does not warrant such dramatic language. It is even less appropriate if one uses my alternative measures in the lower panel (from more recent sources referring to exactly the same periods and concepts).

Table 3 Mandel's evidence scrutinized (annual average compound growth rates)

\begin{tabular}{lll}
\hline & $\begin{array}{l}\text { Second-wave } \\
\text { downswing-pronounced } \\
\text { depression }\end{array}$ & $\begin{array}{l}\text { Third-wave } \\
\text { upswing-tempestuous } \\
\text { increase in economic activity }\end{array}$ \\
\hline Mandel's indicators & & \\
UK industrial output & $1.2(1876-1893)$ & $2.2(1894-1913)$ \\
Germany industrial output & $2.5(1875-1892)$ & $4.3(1893-1913)$ \\
USA industrial output & $4.9(1874-1893)$ & $5.9(1894-1913)$ \\
World trade & $2.2(1870-1890)$ & $3.7(1891-1913)$ \\
Average & 2.7 & 4.0 \\
Mandel replicated & 1.4 & 2.4 \\
UK & 4.0 & 4.2 \\
Germany & 4.9 & 5.0 \\
USA & 3.4 & 3.5 \\
World & 3.4 & 3.8 \\
Average & &
\end{tabular}

Source Top five rows from Mandel (1975), pp 141-142 (omitting his citation of Dupriez's 1947 estimates of world per capita output as these were much too shaky for serious use in this context). Bottom five rows from industrial production including construction for the UK, Germany, and the USA for Mandel's periods from Lewis (1978); world trade volume from Maddison (1962) 


\section{Mandel's stages of development}

Mandel identified "stages" as well as "waves". Here he was influenced by Lenin's (1916) essay on "Imperialism the Highest Stage of Capitalism". He was mainly concerned with "late capitalism" but, interestingly enough, he did not consider it to be a new stage but merely a development within imperialist monopoly-capitalism, which Lenin had distinguished from a first phase of "free competition".

At first sight this is puzzling, for Mandel frequently refers to features of 'late capitalism' (the enhanced role of the state in the economy, the formal ending of colonialism, the importance of military spending, and the changed international power locus) that seem rather different from those described by Lenin. The reason for Mandel's position is explained in his 1975 book (pp 524-525), where he dissociated himself from "revisionists", such as John Strachey (1956), who claimed that there was a new-era mixed economy that can 'suspend the internal economic contradictions of capitalism'.

Thus there was no real connection between Mandel's stages of growth and his long waves. The latter were the fruit of more or less exogenous technological development, and did not have the policy-institutional flavour that Schumpeter conferred on his by calling one 'bourgeois' and another 'neomercantilist'.

\section{Mensch}

Gerhard Mensch (1975), another long-wave revivalist, had a neo-Schumpeterian approach and a detailed catalogue of different types of innovation. He considered that the clustering of innovations determined the tempo of capitalist performance, and that the 1970s slowdown was due to a shortage of exploitable innovations and market saturation. He had interesting ideas about lags in application of inventions, but lapsed frequently into apocalyptic sermonizing. He concentrated on illustrative examples of 'industrial evolution' and presented almost no quantitative evidence on variations in the pace of macroeconomic performance he was presumably trying to explain. He did not discuss inter-country diffusion of innovations, and nowhere made the lead-follower dichotomy, which is fundamental in analysis of technological diffusion.

\section{Conclusions on long-wave theories}

My basic conclusion is that the existence of a regular long-term rhythms in economic activity is not proven, although many fascinating hypotheses have been developed in looking for them. Nevertheless, it is clear that major changes in growth momentum have occurred since 1820, and some explanation is needed. In my view it should not be sought in systematic waves, but 
in specific disturbances of an ad hoc character (14). Major system shocks have changed the momentum of capitalist development at certain points. Sometimes they were more or less accidental in origin; sometimes they occurred because some inherently unstable arrangement could no longer be sustained and finally broke down (e.g., the Bretton Woods fixed exchange rate system). Changes in the institutional-policy mix play a bigger role in capitalist development than many long-wave theorists would admit. A system shock will produce the need for new policy instruments. These are not always selected on the most rational basis, and they may require a long period of experiment before they work properly. There may be conflicts of interest within and between countries which prevent the emergence of efficient policies. Hence there have been prolonged periods in which supply potential was not fully exploited. Some of these problems figure in Schumpeter's analysis but he usually sees the solution as a matter of destiny rather than choice.

Capitalist development since 1820 has a certain unity because economic growth in all phases has been much more rapid than in the merchant capitalist epoch from 1500 to 1820 . Nevertheless, there have been big changes which influenced the type of fluctuations that were experienced in the advanced capitalist economies. These changes have to be kept in mind in constructing any general theory of fluctuations or phases. Increased levels of income and changed patterns of demand and productivity have changed the structure of production and employment. In 1820, agriculture characteristically employed well over half of the labour force in these countries, whereas the average is now nearer 3\%. Agriculture was and still is subject to erratic fluctuations in output owing to weather, and its products have generally been sold in flexprice markets in which prices go down as well as up. This erratic element in economic life is much smaller than it used to be.

Industry provided about a quarter of total employment around 1820 and rose towards a peak of somewhere round $40 \%$ in 1970 in my 16-country sample. Hence the process of capitalist development is often referred to as industrialization. However, the industrial share of employment has been on the decline for more than 30 years, and has now regressed closer to the 1820 proportion than to its peak level. The big long-run gains have been in services, which accounted for a fifth of total employment in 1820 against three-quarters now. It was in the industrial sector that the business cycle was most marked in terms of demand fluctuation and stock-output supply adjustments, but in the service sector both demand and supply have been more stable, and this has dampened the amplitude of fluctuations in GDP.

A second major change in economic life has been the growing role of government. In 1820 government spending was typically less than $10 \%$ of GDP, but the proportion is now much bigger. In the advanced capitalist countries, governments intervene on a massive scale to operate a vast network of social transfers, which change the distribution of income and the pattern of private spending. Total government spending (including transfers) in our 16 countries is now nearly half of GDP. 
The government regulatory role in the economy has greatly increased. One result of the latter is that the stability of financial institutions has improved. Before the Second World War, depressions were often reinforced by major bank failures, but these are now rarer and their impact is cushioned. As a result of these changes, government exercises both a propulsive and a compensatory role in economic life, which generally operates to stabilize the expenditure and income flow, and the aspirations of governments to act as managers of economic destiny have greatly increased.

There are also other changes to keep in mind when developing hypotheses intended to cover the whole capitalist period. One important one is the change in the average size of firms, and the role of trade unions. Hence, the atomized market paradigm is less relevant in wage and price fixing, which explains some of the changes that have occurred in price behaviour. Another is the character of international linkages between countries, the degree to which trade, capital and migration are subject to restrictions and the scope for international transfers of technology. These have varied a good deal over time and have been the most exposed to system shock. There have also been big changes in the international monetary system, which have had a major impact on the type of policy weapons used domestically.

\section{Phases of growth}

Although I find no convincing evidence in the work of Kondratieff and Schumpeter to support the notion of regular or systematic long waves in economic life, there have nevertheless been significant changes in the momentum of capitalist development. These changes in momentum can be seen clearly in our first four graphs, which make binary comparisons of growth performance 1820-2001 in the biggest countries, i.e., France/USA, Germany/ USA, Japan/USA, and UK/USA.

Since 1820 one can identify separate phases which have meaningful internal coherence in spite of wide variations in individual country performance within each of them. Comparative performance is quantified in detail in Tables 4, 5, $6,7,8,9,10,11,12$ and 13 .

Phases are identified, in the first instance, by inductive analysis and iterative inspection of empirically measured characteristics. Annual estimates were derived for as many years as possible since 1820, including war years. Aggregate performance of the sixteen countries is also shown, with both weighted and unweighted averages. For many purposes the unweighted average is the most relevant indicator of the characteristic experience of these countries. The weighted average is a useful supplement, but it should not be forgotten that the USA now has a very large weight in this measure.

My preference is for measures of annual movements in aggregate activity (GDP), which reveal clearly the big changes in the severity of recessions that have appeared systematically across the sixteen advanced capitalist countries shown in Table 4. It is clear that peacetime business cycle history has been 
Table 4 Amplitude of recessions in aggregate output 1820-2001 (maximum peak-trough fall in GDP or lowest rise) (annual data)

\begin{tabular}{lcrrrrrr}
\hline & $1820-1870$ & $1870-1913$ & $1914-1919$ & $1920-1938$ & $1939-1949$ & $1950-1973$ & $1973-2001$ \\
\hline Australia & -13.9 & -17.1 & -6.6 & -15.6 & -11.6 & 0.7 & -0.9 \\
Austria & & -2.3 & -38.2 & -22.5 & -58.7 & 0.1 & -0.4 \\
Belgium & 0.0 & -0.2 & -32.2 & -7.9 & -25.5 & -0.8 & -1.5 \\
Canada & & -8.8 & -6.7 & -29.6 & -4.1 & 0.7 & -3.0 \\
Denmark & -5.6 & -2.7 & -11.8 & -2.9 & -22.5 & 0.6 & -1.6 \\
Finland & & -4.3 & -33.0 & -4.0 & -9.3 & 0.7 & -10.4 \\
France & -7.6 & -8.2 & -36.1 & -14.7 & -53.1 & 2.5 & -1.0 \\
Germany & -2.4 & -3.2 & -30.4 & -16.9 & -62.2 & 0.3 & -2.9 \\
Italy & & -6.7 & -16.7 & -10.1 & -43.8 & 1.9 & -2.1 \\
Japan & & -7.4 & -3.0 & -7.3 & -51.7 & 4.7 & -1.7 \\
Netherlands & -4.5 & -5.9 & -12.2 & -9.5 & -50.1 & -0.3 & -1.7 \\
Norway & & -0.5 & -12.4 & -8.3 & -16.7 & -0.9 & -0.1 \\
Sweden & -9.7 & -5.5 & -15.5 & -6.2 & -3.0 & 0.5 & -4.7 \\
Switzerland & -17.3 & -11.2 & -11.5 & -8.0 & -4.0 & -2.1 & -8.6 \\
UK & -7.0 & -4.1 & -10.9 & -10.4 & -13.4 & -0.6 & -2.9 \\
USA & & -8.2 & -7.7 & -28.5 & -25.0 & -1.0 & -1.9 \\
Arithmetic average & -7.6 & -6.0 & -17.8 & -12.7 & -28.4 & 0.4 & -2.8 \\
Weighted average & & -3.1 & -6.3 & -16.4 & -22.5 & 1.1 & 0.1 \\
\hline Source & & & & & & & \\
\hline
\end{tabular}

Source Maddison (2003). Figures are adjusted to exclude the impact of frontier change. In the first column, estimates for Germany and Switzerland are for the period 1850-1870, 1830-1870 for the UK, and 1846-1870 for Belgium

Table 5 Growth of GDP at constant 1990 prices, 1500-2001 (annual average compound growth rate)

\begin{tabular}{lccccccc}
\hline & $1500-1820$ & $1820-1870$ & $1870-1913$ & $1913-1950$ & $1950-1973$ & $1973-2001$ & $1820-2001$ \\
\hline Australia & -0.01 & 7.28 & 3.44 & 2.47 & 4.60 & 3.26 & 4.41 \\
Austria & 0.33 & 1.45 & 2.41 & 0.25 & 5.35 & 2.38 & 2.06 \\
Belgium & 0.41 & 2.24 & 2.02 & 1.03 & 4.08 & 2.14 & 2.15 \\
Canada & 0.62 & 4.42 & 4.02 & 2.94 & 4.98 & 2.95 & 3.86 \\
Denmark & 0.38 & 1.91 & 2.66 & 2.55 & 3.81 & 2.06 & 2.48 \\
Finland & 0.60 & 1.58 & 2.74 & 2.69 & 4.94 & 2.57 & 2.66 \\
France & 0.37 & 1.43 & 1.63 & 1.15 & 5.05 & 2.20 & 1.99 \\
Germany & 0.37 & 2.00 & 2.81 & 0.30 & 5.68 & 1.75 & 2.26 \\
Italy & 0.21 & 1.24 & 1.94 & 1.49 & 5.64 & 2.30 & 2.17 \\
Japan & 0.31 & 0.41 & 2.44 & 2.21 & 9.29 & 2.71 & 2.71 \\
Netherlands & 0.56 & 1.70 & 2.16 & 2.43 & 4.74 & 2.46 & 2.46 \\
Norway & 0.54 & 1.70 & 2.12 & 2.93 & 4.06 & 3.30 & 2.60 \\
Sweden & 0.66 & 1.62 & 2.17 & 2.74 & 3.73 & 1.83 & 2.28 \\
Switzerland & 0.52 & 1.91 & 2.55 & 2.60 & 4.51 & 1.16 & 2.41 \\
UK & 0.80 & 2.05 & 1.90 & 1.19 & 2.93 & 2.08 & 1.95 \\
USA & 0.86 & 4.20 & 3.94 & 2.84 & 3.93 & 2.94 & 3.63 \\
Arithmetic average & 0.47 & 2.32 & 2.56 & 1.99 & 4.83 & 2.38 & 2.63 \\
Weighted average & 0.41 & 2.00 & 2.69 & 1.97 & 4.75 & 2.58 & 2.59 \\
N & & & & & & &
\end{tabular}

Source Maddison (2003) 
Table 6 Growth of per capita GDP at constant 1990 prices, 1500-2001 (annual average compound growth rate)

\begin{tabular}{llllllll}
\hline & $1500-1820$ & $1820-1870$ & $1870-1913$ & $1913-1950$ & $1950-73$ & $1973-2001$ & $1820-2001$ \\
\hline Australia & 0.08 & 3.36 & 1.06 & 0.99 & 2.43 & 1.90 & 2.09 \\
Austria & 0.17 & 0.85 & 1.45 & 0.18 & 4.94 & 2.12 & 1.56 \\
Belgium & 0.13 & 1.44 & 1.05 & 0.70 & 3.54 & 1.95 & 1.54 \\
Canada & 0.26 & 1.27 & 2.27 & 1.35 & 2.83 & 1.72 & 1.79 \\
Denmark & 0.17 & 0.91 & 1.57 & 1.56 & 3.08 & 1.83 & 1.62 \\
Finland & 0.17 & 0.76 & 1.44 & 1.91 & 4.25 & 2.19 & 1.82 \\
France & 0.14 & 1.01 & 1.45 & 1.12 & 4.04 & 1.71 & 1.63 \\
Germany & 0.14 & 1.08 & 1.61 & 0.17 & 5.02 & 1.60 & 1.59 \\
Italy & 0.00 & 0.59 & 1.26 & 0.85 & 4.95 & 2.10 & 1.58 \\
Japan & 0.09 & 0.19 & 1.48 & 0.88 & 8.06 & 2.14 & 1.91 \\
Netherlands & 0.28 & 0.81 & 0.90 & 1.07 & 3.45 & 1.83 & 1.37 \\
Norway & 0.17 & 0.52 & 1.30 & 2.13 & 3.19 & 2.83 & 1.73 \\
Sweden & 0.17 & 0.66 & 1.46 & 2.12 & 3.06 & 1.52 & 1.58 \\
Switzerland & 0.17 & 1.32 & 1.66 & 2.06 & 3.08 & 0.72 & 1.68 \\
UK & 0.27 & 1.26 & 1.01 & 0.93 & 2.42 & 1.86 & 1.37 \\
USA & 0.36 & 1.34 & 1.82 & 1.61 & 2.45 & 1.86 & 1.73 \\
Arithmetic average & 0.17 & 1.09 & 1.42 & 1.23 & 3.80 & 1.87 & 1.66 \\
Weighted average & 0.14 & 1.11 & 1.57 & 1.21 & 3.64 & 1.92 & 1.68 \\
\hline
\end{tabular}

Source Maddison (2003)

Table 7 Growth characteristics of five phases of capitalist development, 1820-2001 (arithmetic average of figures for the individual countries: annual average compound growth rates)

\begin{tabular}{llll}
\hline Phases & GDP & GDP per capita & Volume of exports \\
\hline $1820-1870$ & 2.32 & 1.09 & 4.2 \\
$1870-1913$ & 2.56 & 1.42 & 3.9 \\
$1913-50$ & 1.99 & 1.23 & 1.1 \\
$1950-73$ & 4.83 & 3.80 & 8.6 \\
$1973-2001$ & 2.38 & 1.87 & 5.0 \\
\hline
\end{tabular}

Source Maddison (1991) and (2003), and Tables 4, 5, 6, 7, 8, 9, 10, 11, 12 and 13

much milder since the Second World War than before, and that the 1920-1938 period was generally much worse than 1870-1913. Except in 1929-1933, when depression hit every country, the weighted average of cyclical movements for the sixteen countries as a group was dampened by the fact that individual country cycles were not synchronized. Table 12 shows the cyclical record for foreign trade. It confirms the pattern shown by GDP movements, with notably smaller cycles since the Second World War.

Table 10 shows the amplitude of annual changes in aggregate GDP for the sixteen countries taken together for the period 1871-2001. For this period we have complete information on annual movement of GDP for all sixteen countries (2,096 readings). Table 11 shows the incidence of recession by country for every year between 1871 and 2001 . The biggest interruptions to growth occurred in 1914-1919, the 1930-1932 depression, and the 1945-1946 period of demobilization, dismemberment, defeat, and victory. All other 
Table 8 Cyclical characteristics of different phases, 1820-2001 (arithmetic average of figures for the individual countries)

\begin{tabular}{lllll}
\hline Phases & $\begin{array}{l}\text { Maximum peak/ } \\
\text { trough GDP } \\
\text { movement }\end{array}$ & $\begin{array}{l}\text { Maximum peak/ } \\
\text { trough export } \\
\text { volume movement }\end{array}$ & $\begin{array}{l}\text { Average } \\
\text { unemployment } \\
\text { rate }\end{array}$ & $\begin{array}{l}\text { Average annual } \\
\text { change in } \\
\text { consumer prices }\end{array}$ \\
\hline $1820-1870$ & -7.6 & n.a. & n.a. & $-0.2^{\mathrm{a}}$ \\
$1870-1913$ & -6.0 & -18.2 & $4.5^{\mathrm{b}}$ & 0.4 \\
$1920-38$ & -12.7 & -36.5 & 7.3 & $-0.7^{\mathrm{c}}$ \\
$1950-73$ & +0.4 & -7.0 & 2.6 & 4.1 \\
$1973-2001$ & -2.8 & -8.2 & 6.5 & 5.3 \\
$1973-83$ & & & 5.2 & 9.3 \\
$1983-2001$ & & & 7.3 & 3.0 \\
\hline
\end{tabular}

a UK only

b UK and USA 1900-1913

c 1924-1938 for Austria and Germany, 1921-1938 for Belgium

Source Appendices to Maddison (1991, 1997, pp 472-473, 2001, p 134), OECD, Economic Outlook, 2002, 1 and Table 11 below. UK price index 1820-1870 from Mitchell (1962, pp 471-474)

disturbances had a much milder impact on output. The aggregate stability in the collective output of the group in peacetime has been quite impressive. In the 43 years from 1870 to 1913 , there were only 3 years of recession in aggregate output, in the 27 years 1947-1973 none, and in the 28 years 19732001 only one occasion when aggregate output fell. However, it is clear from Table 11 that individual countries have been much more unstable than the group as a whole. Their cyclical experience has not normally been synchronized, but compensatory. Cyclical experience has been synchronized only when they have been subjected to 'system-shocks' such as wars, or the collapse of long-standing international payments mechanisms, as in the in the 33 years 1914-1946, there were 9 years in which aggregate GDP of the sixteen countries fell.

For 1820-1870, the statistical coverage is weaker. The annual estimates are complete for Australia, Denmark, France, the Netherlands, and Sweden. For the UK there is coverage for 42 years, for Belgium for 27 years, 23 for Germany and less elsewhere. Altogether there are 418 annual readings out of a potential 800 . However, judging from the evidence we have, it seems that average cyclical experience in 1820-1870 was not too different from that of 1871-1913 Tables 12 and 13.

My primary interest is in identifying major changes in growth momentum rather than shorter-term oscillations. There is a need for annual time series for major indicators of aggregate economic activity for our sixteen countries in as complete and comparable a form as possible and a special need to get coverage for all of the countries for the initial benchmark year 1820. By inspection of the data and graphs derived from them, one can identify fundamental turning points in growth momentum, and try to distiguish growth and cyclical behaviour patterns that differ significantly between phases. The technique is not unlike that of the NB ER in its attempt to identify reference cycles, and in 


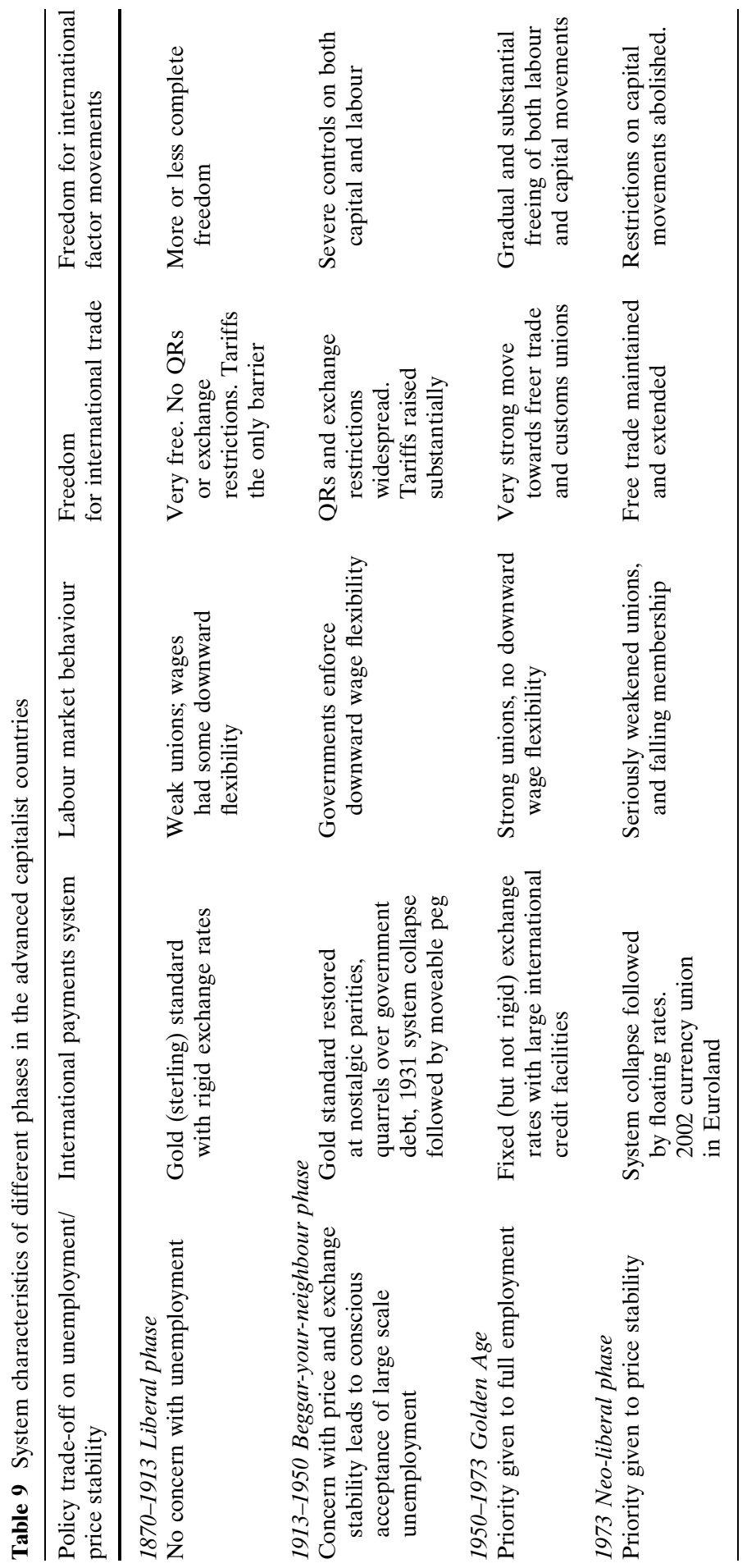


Table 10 Annual percentage change in agregate gdp (16 countries), 1871-2001

\begin{tabular}{|c|c|c|c|c|c|}
\hline 1871 & 2.3 & 1914 & -6.3 & 1957 & 3.4 \\
\hline 1872 & 3.7 & 1915 & 2.6 & 1958 & 1.1 \\
\hline 1873 & 2.0 & 1916 & 7.9 & 1959 & 6.4 \\
\hline 1874 & 3.7 & 1917 & -2.3 & 1960 & 5.2 \\
\hline 1875 & 3.2 & 1918 & 1.2 & 1961 & 4.2 \\
\hline 1876 & -1.1 & 1919 & -3.0 & 1962 & 5.7 \\
\hline 1877 & 1.8 & 1920 & 0.4 & 1963 & 4.7 \\
\hline 1878 & 1.9 & 1921 & -0.5 & 1964 & 6.4 \\
\hline 1879 & 1.9 & 1922 & 7.0 & 1965 & 5.2 \\
\hline 1880 & 6.2 & 1923 & 4.8 & 1966 & 5.6 \\
\hline 1881 & 2.3 & 1924 & 5.5 & 1967 & 3.8 \\
\hline 1882 & 4.1 & 1925 & 4.2 & 1968 & 5.8 \\
\hline 1883 & 2.1 & 1926 & 3.5 & 1969 & 5.3 \\
\hline 1884 & 1.2 & 1927 & 3.0 & 1970 & 3.4 \\
\hline 1885 & 0.7 & 1928 & 3.4 & 1971 & 3.4 \\
\hline 1886 & 2.4 & 1929 & 3.9 & 1972 & 5.1 \\
\hline 1887 & 3.7 & 1930 & -5.1 & 1973 & 5.9 \\
\hline 1888 & 1.5 & 1931 & -6.1 & 1974 & 0.7 \\
\hline 1889 & 3.7 & 1932 & -6.2 & 1975 & 0.1 \\
\hline 1890 & 2.4 & 1933 & 2.0 & 1976 & 4.6 \\
\hline 1891 & 1.3 & 1934 & 5.2 & 1977 & 3.6 \\
\hline 1892 & 3.2 & 1935 & 5.5 & 1978 & 4.4 \\
\hline 1893 & -0.2 & 1936 & 8.3 & 1979 & 3.9 \\
\hline 1894 & 2.1 & 1937 & 4.8 & 1980 & 1.1 \\
\hline 1895 & 4.9 & 1938 & 0.6 & 1981 & 1.7 \\
\hline 1896 & 1.4 & 1939 & 7.4 & 1982 & -0.1 \\
\hline 1897 & 3.6 & 1940 & 2.7 & 1983 & 2.8 \\
\hline 1898 & 4.8 & 1941 & 8.0 & 1984 & 4.8 \\
\hline 1899 & 4.8 & 1942 & 8.5 & 1985 & 3.5 \\
\hline 1900 & 2.1 & 1943 & 9.3 & 1986 & 3.0 \\
\hline 1901 & 3.6 & 1944 & 2.2 & 1987 & 3.3 \\
\hline 1902 & 0.9 & 1945 & -10.4 & 1988 & 4.4 \\
\hline 1903 & 3.5 & 1946 & -13.5 & 1989 & 3.6 \\
\hline 1904 & 0.8 & 1947 & 2.3 & 1990 & 1.9 \\
\hline 1905 & 4.2 & 1948 & 5.8 & 1991 & 0.8 \\
\hline 1906 & 6.7 & 1949 & 4.2 & 1992 & 1.9 \\
\hline 1907 & 3.2 & 1950 & 7.9 & 1993 & 1.2 \\
\hline 1908 & -3.1 & 1951 & 7.0 & 1994 & 3.1 \\
\hline 1909 & 6.2 & 1952 & 4.1 & 1995 & 2.4 \\
\hline 1910 & 1.2 & 1953 & 5.0 & 1996 & 2.8 \\
\hline 1911 & 4.2 & 1954 & 2.4 & 1997 & 3.2 \\
\hline 1912 & 4.0 & 1955 & 6.9 & 1998 & 2.9 \\
\hline \multirow[t]{3}{*}{1913} & 3.3 & 1956 & 3.6 & 1999 & 3.0 \\
\hline & & & & 2000 & 3.4 \\
\hline & & & & 2001 & 0.5 \\
\hline
\end{tabular}

Source Maddison (2003)

particular does not involve elaborate decomposition of time series into different kinds of oscillatory movement. Simple techniques are almost inevitable in handling information for sixteen countries, where each series, if it were available for the full 181 years would involve more than 2,896 readings.

Tables 5 and 6 show growth performance (GDP and GDP per capita, respectively) in the five phases (1820-1870, 1870-1913, 1913-1950, 1950-1973, 
Table 11 Incidence of recessions in GDP, by country, 1871-2001 (number of falls in GDP and countries in which GDP fell)

\begin{tabular}{|c|c|c|c|c|c|c|c|c|}
\hline Year & Falls & Countries & Year & Falls & Countries & Year & Falls & Countries \\
\hline 1871 & 4 & AFGN & 1914 & 12 & ATBCLFGIJNSE & 1957 & 0 & \\
\hline 1872 & 3 & CIZ & 1915 & 7 & ATBDLFG & 1958 & 6 & BNWZKE \\
\hline 1873 & 3 & TDF & 1916 & 4 & ATSZ & 1959 & 0 & \\
\hline 1874 & 2 & NE & 1917 & 11 & ATBDLFNWSZE & 1960 & 0 & \\
\hline 1875 & 4 & BCSE & 1918 & 11 & ATBCDLFNWSZ & 1961 & 0 & \\
\hline 1876 & 7 & ACFGIJZ & 1919 & 5 & TCGIK & 1962 & 0 & \\
\hline 1877 & 5 & DLGSZ & 1920 & 5 & CIJKE & 1963 & 0 & \\
\hline 1878 & 6 & CLFJWS & 1921 & 9 & CDFIWSZKE & 1964 & 0 & \\
\hline 1879 & 7 & TFGNSZK & 1922 & 1 & $\mathrm{~J}$ & 1965 & 0 & \\
\hline 1880 & 1 & G & 1923 & 2 & TG & 1966 & 0 & \\
\hline 1881 & 3 & LIJ & 1924 & 1 & W & 1967 & 0 & \\
\hline 1882 & 3 & AWZ & 1925 & 1 & $\mathrm{D}$ & 1968 & 0 & \\
\hline 1883 & 2 & IW & 1926 & 1 & $\mathrm{~K}$ & 1969 & 0 & \\
\hline 1884 & 1 & $\mathrm{~F}$ & 1927 & 2 & FI & 1970 & 0 & \\
\hline 1885 & 5 & TCFSK & 1928 & 0 & & 1971 & 0 & \\
\hline 1886 & 1 & $\mathrm{~S}$ & 1929 & 4 & ABCG & 1972 & 0 & \\
\hline 1887 & 1 & $\mathrm{Z}$ & 1930 & 13 & ATBCLFGIJNZKE & 1973 & 0 & \\
\hline 1888 & 3 & TJE & 1931 & 14 & ATBCLFGINWSZKE & 1974 & 4 & DJKE \\
\hline 1889 & 2 & TI & 1932 & 11 & TBCDLFGNSZE & 1975 & 10 & TBDFGINZKE \\
\hline 1890 & 2 & AN & 1933 & 5 & TCINE & 1976 & 2 & $\mathrm{LZ}$ \\
\hline 1891 & 5 & LGJNZ & 1934 & 3 & BFN & 1977 & 1 & $\mathrm{~S}$ \\
\hline 1892 & 5 & ACLIK & 1935 & 2 & FZ & 1978 & 1 & $\mathrm{~T}$ \\
\hline 1893 & 3 & ACE & 1936 & 0 & & 1979 & 0 & \\
\hline 1894 & 3 & IZE & 1937 & 0 & & 1980 & 2 & DK \\
\hline 1895 & 3 & $\mathrm{ACF}$ & 1938 & 4 & BFNE & 1981 & 5 & TBDNK \\
\hline 1896 & 4 & CJNE & 1939 & 2 & $\mathrm{LZ}$ & 1982 & 6 & ACGNZE \\
\hline 1897 & 3 & AFI & 1940 & 8 & TBDLFNWS & 1983 & 0 & \\
\hline 1898 & 0 & & 1941 & 6 & BDFINZ & 1984 & 0 & \\
\hline 1899 & 2 & LJ & 1942 & 8 & TBFIJNWZ & 1985 & 0 & \\
\hline 1900 & 2 & FK & 1943 & 6 & BFINWZ & 1986 & .0 & \\
\hline 1901 & 6 & ALFGSZ & 1944 & 7 & AFIJNWK & 1987 & 0 & \\
\hline 1902 & 5 & LFIJS & 1945 & 10 & ATCDLGIJKE & 1988 & 1 & W \\
\hline 1903 & 3 & WZK & 1946 & 5 & ACGKE & 1989 & 0 & \\
\hline 1904 & 2 & WE & 1947 & 2 & $\mathrm{KE}$ & 1990 & 1 & G \\
\hline 1905 & 1 & $\mathrm{~J}$ & 1948 & 0 & & 1991 & 7 & ACLSZKE \\
\hline 1906 & 0 & & 1949 & 1 & $\mathrm{Z}$ & 1992 & 3 & LSZ \\
\hline 1907 & 0 & & 1950 & 1 & $\mathrm{~K}$ & 1993 & 7 & BLFGISZ \\
\hline 1908 & 6 & CFSZKE & 1951 & 0 & & 1994 & 0 & \\
\hline 1909 & 3 & TJS & 1952 & 2 & BK & 1995 & 0 & \\
\hline 1910 & 2 & FI & 1953 & 0 & & 1996 & 0 & \\
\hline 1911 & 0 & & 1954 & 2 & $\mathrm{CE}$ & 1997 & .0 & \\
\hline 1912 & 0 & & 1955 & 0 & & 1998 & 1 & $\mathrm{~J}$ \\
\hline \multirow[t]{3}{*}{1913} & 1 & $\mathrm{Z}$ & 1956 & 0 & & 1999 & 0 & \\
\hline & & & & & & 2000 & 0 & \\
\hline & & & & & & 2001 & 1 & $\mathrm{~J}$ \\
\hline
\end{tabular}

$A$ Australia, $T$ Austria, $B$ Belgium, $C$ Canada, $D$ Denmark, $L$ Finland, $F$ France, $G$ Germany, $I$ Italy, $J$ Japan, $N$ Netherlands, $W$ Norway, $S$ Sweden, $Z$ Switzerland, $K$ UK, $E$ USA

Source Maddison (2003) 
Table 12 Amplitude of recessions in exports, 1870-2001 (maximum peak-trough fall or smallest rise in volume, annual data)

\begin{tabular}{lclll}
\hline & $1870-1913$ & $1920-1938$ & $1950-1973$ & $1973-2001$ \\
\hline Australia & -32.2 & -19.7 & -7.6 & -3.6 \\
Austria & (n.a.) & -48.7 & -7.3 & -5.5 \\
Belgium & -13.1 & -31.8 & -9.6 & -6.8 \\
Canada & -13.9 & -40.6 & -6.1 & -10.3 \\
Denmark & -25.0 & -20.3 & -6.7 & -4.1 \\
Finland & -20.9 & -15.7 & -13.4 & -17.4 \\
France & -12.9 & -47.3 & -12.0 & -4.0 \\
Germany & -14.2 & -50.1 & +2.3 & -11.5 \\
Italy & -30.6 & -69.1 & -9.1 & -8.5 \\
Japan & -23.7 & -18.9 & 0.0 & -10.9 \\
Netherlands & -14.8 & -33.4 & +2.6 & -3.8 \\
Norway & -7.7 & -16.0 & -7.1 & -3.3 \\
Sweden & -11.0 & -37.0 & -10.7 & -11.6 \\
Switzerland & $(\mathrm{n} . \mathrm{a})$. & -50.2 & -4.2 & -8.2 \\
UK & -12.5 & -37.7 & -8.0 & -2.2 \\
USA & -18.9 & -47.8 & -14.3 & -18.8 \\
Arithmetic average & -18.0 & -36.5 & -7.0 & -8.2 \\
\hline
\end{tabular}

Source Maddison (1991, App. F, updated from 1985 from OECD, Economic Outlook, June 2003, p 233. Dutch estimates for 1870-1913 supplied by Jan Pieter Smits

Table 13 Growth in volume of exports, 1720-2001 (annual average compound growth rate)

\begin{tabular}{lccccccc}
\hline & $1720-1820$ & $1820-70$ & $1870-1913$ & $1913-50$ & $1950-73$ & $1973-2001$ & $1870-2001$ \\
\hline Australia & & 4.8 & 1.3 & 5.8 & 5.3 & 4.0 \\
Austria & & 4.7 & 3.5 & -1.1 & 10.7 & 7.3 & 4.2 \\
Belgium & 5.3 & 4.2 & 0.3 & 9.2 & 4.4 & 4.0 \\
Canada & & 4.1 & 3.1 & 7.0 & 5.7 & 4.7 \\
Denmark & & $1.9^{\mathrm{a}}$ & 3.7 & 2.4 & 6.9 & 4.7 & 4.1 \\
Finland & & 3.9 & 1.9 & 7.2 & 4.6 & 4.0 \\
France & $1.0^{\mathrm{b}}$ & 4.0 & 2.8 & 1.1 & 8.2 & 4.9 & 3.7 \\
Germany & & $4.8^{\mathrm{c}}$ & 4.1 & -2.8 & 12.4 & 4.8 & 3.6 \\
Italy & & 3.4 & 2.2 & 0.6 & 11.6 & 5.2 & 4.0 \\
Japan & & & 8.5 & 2.0 & 15.4 & 4.7 & 7.0 \\
Netherlands & -0.2 & 5.5 & $2.3 \mathrm{~d}$ & 1.5 & 10.4 & 4.4 & $3.9^{\mathrm{d}}$ \\
Norway & & & 3.2 & 2.7 & 7.3 & 6.4 & 4.4 \\
Sweden & & & 3.1 & 2.8 & 6.9 & 4.5 & 4.0 \\
Switzerland & & 4.1 & 3.9 & 0.3 & 8.1 & 3.0 & 3.4 \\
UK & \multirow{2}{*}{2.0} & 4.9 & 2.8 & 0.0 & 3.9 & 4.5 & 2.5 \\
USA & & 4.7 & 4.9 & 2.2 & 6.3 & 5.6 & 4.5 \\
Arithmetic average & & 4.3 & 3.9 & 1.1 & 8.6 & 5.0 & 4.1 \\
\hline
\end{tabular}

\footnotetext{
a $1844-1870$

b $1715-1820$

c $1840-1870$

d $1872-2001$
}

Source Maddison (1991, p 75, updated and amended from Maddison 2001, p 361) and OECD, Economic Outlook, June 2003. Dutch estimates for 1820-1913 supplied by Jan Pieter Smits 
and 1973 onwards) I have identified within the capitalist epoch. They also compare the pace of progress in the capitalist epoch as a whole (1820 onwards), with that in the preceding merchant-capitalist epoch (1500-1820).

It is clear that growth momentum in the first phase (1820-1870) was much faster than that in the merchant capitalist epoch; it accelerated somewhat in 1870-1913. 1913-1950 was the period when performance was worst. Extreme shocks struck three times between 1914s and the 1940s. Performance in the unprecedented postwar boom-the golden age, 1950-1973, was also very special in Western Europe and Japan. The nature of the growth process changed sharply after 1973.

Kuznets (1963), in his critique of Rostow's stage schema (15), postulated five minimum requirements for acceptable stages of growth: (a) they must be identified by characteristics that can be verified or quantified; (b) the magnitude of these characteristics must vary in some recognizable pattern from one phase to another: "stages are presumably something more than successive ordinates in the steadily climbing curve of growth. They are segments of that curve with properties so distinct that separate study of each segment seems warranted"; (c) there should be some indication of when stages terminate and begin and why; (d) it is necessary to identify the universe to which the stage classification applies; (e) finally, Kuznets required that there be an analytic relation between successive "stages", which, optimally, would make it possible to predict how long each stage has to run. This fifth requirement seems too deterministic. It suggests that movements between successive stages are more or less ineluctable. I have tried to fulfill Kuznets' first four requirements, but cannot meet his fifth condition. For this reason, I have called my periods "phases" rather than "stages". Tables 7 and 8 summarise the main kinds of evidence I used.

My growth phases fulfil the first four Kuznets' requirements as explained below.

(a) They are identified by seven simple indicators: rate of growth of the volume of output, output per head and exports: cyclical variations in output and exports, unemployment, and rate of change in consumer prices. These are the conventional macroeconomic indicators one might use for growth accounting or conjunctural monitoring. The results are shown in very aggregative form in Tables 7 and 8 . Each phase also has five non-quantifiable 'system characteristics', by which I mean the basic policy approaches and institutional environment that condition growth performance. Changes in these between periods are summarised in Table 9 These include the government approach to demand management (i.e., the kind of trade-off that is made between unemployment and inflation), the bargaining power of labour, the degree of freedom for trade and international factor movements, and the character of the international payments mechanism.

(b) Most of these characteristics are systematically different in the phases identified. Generally, they were most favourable in the "golden age" 
1950-1973, second-best in the latest phase (1973 onwards), third-best in the 'liberal'phase and worst in the 'beggar-your-neighbour' phase' (1913-1950).

(c) There is room for argument as to which years are turning points between phases. I picked 1820 as the starting point for capitalist development. The evidence now available suggests that the transition to the accelerated growth that distinguishes capitalist from merchant capitalist momentum took place after the Napoleonic wars rather than in 1760 as Kuznets thought. There is also strong evidence that the acceleration of growth was synchronous in western Europe from this time and not staggered throughout the nineteenth century as Gerschenkron and Rostow believed. The year 1870 is an appropriate turning point as it marked the emergence of Germany and Italy as integrated nation states, the emergence of the new growth-oriented Meiji regime in Japan and a USA reunited after civil war. The year 1913 is clearly the last year of a 'liberal' phase, which ended with the outbreak of the First World War. The year 1950 was the point where recovery from the Second World War was completed and the previous peak in output for the sixteen countries as a whole surpassed. However, five countries did not surpass their wartime output peaks until 1953 (Austria, Germany, Japan, UK, and USA), so one might well argue that 1953 rather than 1950 should mark the beginning of the postwar golden age. On the other hand, there is a case for starting in 1948, which is when the ground rules for international cooperation within the capitalist group were set up by the Marshall Plan. The year 1950 seems a reasonable compromise. It should be noted that use of 1948-1973 or 1953-1973 instead of 1950-1973 would not affect the analysis seriousl. This golden age would still be a period of secular boom on an unparalleled scale, and the preceding phase, which encompassed two world wars and a world depression would still have the worst performance.

(d) The emergence of a new phase after 1973 is rather clear. The 1974-1975, 1980-1982 and 1991-1993 recessions affected virtually all sixteen countries. They were by far the biggest breaks in the postwar growth momentum. The grounds for treating the post-1973 period as a new phase include price, unemployment and output behaviour, changes in the international monetary system, in government policy concerning the level of demand, in expectations in the labour market, and greater openness of capital markets. The economic system behaves in a different way, which has created major new tasks for economic policy, and makes it more difficult to reconcile different policy objectives. Table 8 , shows a breakdown within the latest phase of inflationary and unemployment experience. A major reason for changes in macroeconomic objectives in this period was the sharp acceleration in the rate of price rise from 1973 to 1983, due to the two oil shocks and the breakdown of the Bretton Woods international payments system. This led countries to abandon Keynesian full employment objectives in favour of deflationary policy. 
These drastic policy changes were successful in cutting the pace of inflation after 1983, but much higher levels of unemployment became endemic, except in the UK and USA where economic policy has been more expansionist than was the case in most west European countries and Japan. The income safety-net provided by extensive welfare payments in west European countries was an important influence cushioning demand in a situation where recessionary experience might well have been bigger.

\section{Main conclusions on phases}

(1) There have been five distinct phases of economic performance in the capitalist epoch, each with its own momentum.

(2) Phases of growth are not ineluctable, and within each there is considerable scope for variation in country performance; but the policy-institutional framework and policy attitudes characteristic of each phase have had a striking distinctiveness and generality of acceptance. The expectations of economic agents about growth and inflation have also had distinctive characteristics which differed between phases.

(3) The transition from one phase to another was caused by system-shocks. Some were due to a predictable breakdown of a basic characteristic of a previous phase, but the timing of the change was usually governed by exogenous or accidental events which are not predictable.

(4) The present phase generally ranks as second-best. Performance is well below that in 1950-1973 in almost all important respects, but the economies have been a good deal more stable in real terms than before 1950, and per capita output growth has been significantly better.

\section{Endnotes}

(1) William Stanley Jevons (1835-1882) initiated business cycle research in England in 1862, by adjusting time series on business activity to eliminate seasonal variation. He analysed longer term price movements in a brilliant study (1863) of the impact of surging Californian and Australian gold production in the 1850s. In 1878-1879, he estimated the average periodicity of "commercial crises", and the influence of variations in solar activity (sun-spots) on agricultural output. His essays on these topics were collected and published posthumously in 1884 (see Keynes' 1936 assessment of Jevons' work on cycles).

(2) See Burns and Mitchell, op. cit., p 270 states their reasons for not eliminating trend: "cyclical fluctuations are so closely interwoven with these secular changes in economic life that important clues to the understanding of the former may be lost by mechanically eliminating the latter. It is primarily for this reason that we take as our basic unit of analysis a business cycle that includes that portion of secular trend falling within its boundaries." 
(3) In the period 1889-1978, the NBER recorded 21 reference cycles, the industrial production index showed fifteen recessions, and GDP thirteen. The average amplitude of GDP recessions was a $6.5 \%$ fall, and of industrial production, $13.3 \%$.

(4) Burns became less directly involved in NBER research in 1953, when he was appointed chairman of the Council of Economic Advisors to President Eisenhower. He was later Chairman of the Federal Reserve Bank, and Ambassador to Germany. His successors in directing NBER research were Soloman Fabricant 1952-1965; Geoffrey Moore 1965-1967; John Meyer 19671977; and Martin Feldstein since 1977. Fabricant's interests were close to those of Kuznets. He published The Output of Manufacturing Industries, 1899-1937 in 1940, and Employment in Manufacturing, 1899-1939, in 1942. Corresponding work on agriculture was produced by Barger and Landsberg in 1942, and on distribution by Barger in 1955. These buttressed the evidence on US growth in Kuznets' major studies published by NBER in the 1930s and 1940s (see detail in Publications, 1921-1990, NBER, 1990). A survey and assessment of NBER work on business cycles from the 1920s to 1990s is contained in Zarnowitz (1992).

(5) see the discussion in Freeman and Louçã pp 73-74 on the work of the Russian Marxist Parvus (pseudonym of Alexander Helfand 1869-1924), who was the first to assert that capitalism was characterised by longer waves than the business cycle-undulatory jumps in capital formation, followed by contractions. These were 'laws of capitalist oscillation', but he presented no evidence to back this idea. He influenced van Gelderen, who did a much better job in providing statistical and annalistic evidence for the existence of long waves, and made much less ambitious claims. DeWolff (1878-1960) a jewish Dutch socialist, who survived the Nazi concentration camps, accepted and extended van Gelderen's work back to the 1820s in his 1924 contribution to Kautsky's Festschrift. Translations of Parvus and de Wolff can be found in Louçã and Reijnders.

(6) Kondratieff's (1924-1925), trip is described in chapter 4 of Barnett (1998). In a conversation with Kuznets in June 1980, I gathered that his meeting with Kondratieff in Cornell was arranged by his brother Solomon.

(7) The most sophisticated discussion of the Kondratieff wave in prices for the 1870-1913 period is contained in Lewis (1978), which examines whether prices influenced output movements or output influenced prices. Lewis also discusses the role of gold production. His conclusion is that the global price movement in this period was most strongly influenced by US agricultural production. Although Lewis uses personalized nomenclature for various cycles and waves, as Schumpeter also did, he did not in fact endorse the idea of Kondratieff waves as a non-monetary phenomenon on an international scale.

(8) See Burns and Mitchell, op. cit., p 428: "Kuznets did not draw up a list of dates showing the peaks and troughs of his 'secondary secular variations'. In attempting to determine such a chronology from his American series, we found their turning points so widely dispersed that we could have little confidence in any list we ourselves might extract." 
(9) see "Long Swings in Population Growth and Related Economic Variables", reprinted in S. Kuznets, Economic Growth and Structure, Heinemann, London, 1965. See also S. Kuznets, Capital in the American Economy, Princeton, 1961, Chapters 2, 7, 8 and 9.

(10) The others include Brinley Thomas (1954), Jeffrey Williamson (1964), Richard Easterlin (1968) and Arthur Lewis (1978).

(11) In fact, Schumpeter was not too explicit on his chronology, which we owe to Kuznets' exegesis after consultation with Schumpeter; see Kuznets (1940), for a highly sceptical assessment.

(12) See van Duin (1979), an eclectic revivalist, rather cavalier with the few empirical facts he presented; and Forrester (1977), who produced long waves with no data. Well documented scepticism about long waves can be found in Schröder and Spree (1981), and Reijnders (1988).

(13) Kondratieff may not have proved much more than van Gelderen-i.e., that there were long swings in the general price level-but in terms of analytic framework and statistical technique, what Kondratieff offered was distinctly novel.

(14) Freeman and Louçã (2001), p 97 present a taxonomy of alternative approaches to analysis of long waves and phases of capitalist development. Freeman classifies me, together with himself and Trotsky, as a practioner of the historical approach. He classifies Kuznets and Kondratieff as practitioners of the statistical or econometric approach.

(15) See S. Kuznets in W.W. Rostow (ed.), The Economics of Take-Off into Sustained Growth, Macmillan, London, 1963.

\section{References}

Abramovitz M (1959) Statement to the Joint Economic Committee, US Congress, Hearings on Employment, Growth, and Price Levels, Part 2 of Historical and Comparative Rates of Production, Productivity and Prices, pp 411-66

Abramovitz M (1961) The nature and significance of Kuznets' cycles. Econ Dev Cult Change, April

Abramovitz M (1968) The passing of the Kuznets' cycle. Economica, November

Abramovitz M (1986) Simon Kuznets, 1901-1985. J Econ Hist, March

Abramovitz M (1989) Thinking about growth. Cambridge University Press, Cambridge

Abramovitz M (2000) Days gone by: a memoir for my family. Stanford website

Aftalion A (1913) Les crises périodiques de surproduction, 2 vol, Rivière, Paris

Barger H, Landsberg HH (1942) American agriculture, 1899-1939, NBER, New York

Barnett V (1998) Kondratiev and the dynamics of economic development: long cycles and growth in historical perspective. Macmillan, London

Beales HL (1934) The great depression in industry and trade. Econ Hist (review)

Burns AF (1934) Production trends in the United States since 1870. NBER, New York

Burns AF, Mitchell WC (1947) Measuring business cycles. NBER, New York

Bronfenbrenner M (1969) Is the business cycle obsolete? Wiley, New York

Chayanov AV (1986) The theory of peasant economy, Manchester University Press, contains a translation of his 1924 essay "On the theory of non-capitalist economic systems", and 1925 book Peasant Farm Organisation

van Duin JJ (1979) De lange golf in de economie, Van Gorcum, Assen;translated as The long wave in economic life. Allen \& Unwin, London, 1983 
Dupriez LH (1947) Des Mouvements economiques généraux, Louvain

Easterlin RA (1968) Population, labor force, and long swings in economic growth. NBER, New York

Forrester JW (1977) Growth cycles, De Economist, vol 125, pp 525-543

Freeman C (1996) Long wave theory. Elgar, Cheltenham

Freeman C, Louçã F (2001) As time goes by. Oxford University Press, Oxford

Garvy G (1943) Kondratieff's theory of long cycles. Rev Econ Stat

van Gelderen J (1913) Springvloed-beschouwingen over industrielle ontwikkeling en prijsbeweging. De Nieuwe Tijd, pp 253-277, 371-384 and 445-464. (published under pseudonym J, Fedder), English translation in Freeman, 1996

Goldstein JS (1988) Long cycles: prosperity and war in the Modern Age. Yale University Press, New Haven

Jevons WS (1884) Investigations in currency and finance. Macmillan, London

Juglar C (1856) Des crises commerciales. Annuaire de l'economie politique, 13

Juglar C (1862) Des crises commerciales et de leur retour périodique en France, en Angleterre et aux Etats Unis, (2nd edn, 1886 reprinted by Kelley, New York in 1967)

Keynes JM (1936) William Stanley Jevons, reprinted in essays in biography. In: Collected writings, vol X, Macmillan, London, 1972

Kitchin J (1923) Cycles and trends in economic factors. Rev Econ Stat

Kondratieff ND (1922) Mirovoe khoziastyo i ego konjunktury vo vremya I posle voiny, Vologda

Kondratieff ND (1925a) The static and the dynamic view of economics. Quart J Econ

Kondratieff ND (1925b) "Bolshoie tsikly konyunktury" in Voprosy Konyunktury, 1/1

Kondratieff ND (1926) Die langen Wellen der Konjunktur. Archiv für Sozialwissenschaft und Sozialpolitik, 56:573-609. (Abbreviated German translation of 1925b article)

Kondratieff ND (1928b)Die Preisdynamik der industriellen und landwirtschaftlichen Waren (Zum Problem der relativen Dynamik und Konjunktur). Archiv für Sozialwissenschaft und Sozialpolitik 60: $1-85$

Kondratieff ND (1992) Les grands cycles de la conjuncture, Economica, Paris, French translation of 4 articles and Kondratieff-Oparin (1928a), with an introductory assessment by Louis Fontvieille

Kondratieff ND (1998) see Makasheva et al.

Kondratieff ND, Oparin DI (1928a) Bolshoie tsikly konyunktury. Economic Institute, Moscow

Kuznets S (1926) Cyclical fluctuations: retail and wholesale trade, United States, 1929-1925. PhD thesis, Columbia University, Adelphi, New York

Kuznets S (1930) Secular movements in production and prices. Houghton Mifflin, Boston

Kuznets S (1940) Schumpeter's business cycles. Am Econ Rev

Kuznets S (1956) Level and variability of rates of growth. Econ Dev Cult Change

Kuznets S (1958) Long swings in population growth and related economic variables. In: Proceedings of the American Philosophic Society, February, reprinted in Kuznets (1965)

Kuznets S (1961) Capital in the American Economy, Princeton

Kuznets S (1963) Notes on the Takeoff in Rostow

Kuznets S (1965) Economic growth and structure. Heinemann, London

Kuznets S (1971) Economic growth of nations. Harvard

Lenin VI (1916) Imperialism: the highest stage of capitalism. Reprinted in Varga and Mendelsohn

Lewis WA (1978) Growth and fluctuations 1870-1913. Allen \& Unwin, London

Louçã F, J Reijnders (eds) (1999) The foundations of long wave theory, vol 2, Elgar, Cheltenham

Maddison A (1960) The postwar business cycle in Western Europe and the role of Government Policy. Banca Nazionale del Lavoro Quart Rev

Maddison A (1962) Growth and fluctuation in the world economy 1870-1960. Banca Nazionale del Lavoro Quart Rev

Maddison A (1991) Dynamic forces in capitalist development. Oxford University Press, Oxford

Maddison A (1997) The nature and functioning of European capitalism: a historical and comparative perspective. Banca Nazionale del Lavoro Quart Rev

Maddison A (2001) The world economy: a millennial perspective. OECD, Paris

Maddison A (2003) The world economy: historical statistics. OECD, Paris

Maddison A (2005) Measuring and interpreting world economic performance, 1500-2001. Rev Income Wealth 
Makasheva N, Samuels W, Barnett V (1998) The works of Nikolai D. Kondratieff, vol 4. Pickering and Chatto, London

Mandel E (1975) Late capitalism, New Left Books, London (originally published in German in 1972)

Mensch G (1975) Das technologische Patt, Frankfurt; translated as Stalemate in Technology, Ballinger, Cambridge, 1979

Menshikov SM (1984) Strukturnie krisisi v economike capitalisma. Kommunist 4

Menshikov SM, Klimenko LA (1989) Dlinnie Volny v Ekonomike. Mezdunarodnie Otnoschenia, Moscow

Mitchell WC (1927) Business cycles: the problem and its setting. NBER, New York

Mitchell BR (1962) Abstract of British historical statistics. Cambridge University Press, Cambridge

Mitchell WC, King WI, Macaulay FR, Knauth OW (1921) Income in the United States: its amount and distribution, vol. 1 summary; vol. 2 detailed report, NBER, New York

Parvus (1901) Handelskrisis und Gewerkschaften, Munich

Reijnders JPG (1988) The enigma of the long wave, PhD thesis, Groningen

Rosenberg H (1943) Political and other social consequences of the great depression of 1873-1896. Econ Hist Rev pp 58-61

Rostow WW (ed.) (1963) The economics of take-off into sustained growth. Macmillan, London

Rostow WW (1975) Kondratieff, Schumpeter and Kuznets: trend periods revisited. J Econ Hist

Rostow WW (1978) The World economy. Macmillan, London

Schröder WH and Spree R (eds) (1981) Historische Konjunkturforschung. Klett Cotta, Stuttgart

Schumpeter JA (1931) Mitchell's business cycles. Quart J Econ vol. XLV

Schumpeter JA (1939) Business cycles. Mc Graw-Hill, New York

Schumpeter JA (1943) Capitalism, socialism and democracy. Allen \& Unwin, London

Spiethoff A (1923) "Krisen", Handwörterbuch der Staatswissenschaften, English translation "Business cycles". Int Econ Pap, no. 3, 1953

Strachey J (1956) Contemporary capitalism. Gollancz, London

Tooze JA (1999) Weimar's statistical economics: Ernst Wagemann, the Reich's Statistical Office, and the Institute for Business Cycle Research, 1925-1933. Econ Hist Rev pp 523-543

Tugan-Baranowsky M (1894) Promyshlennie krizisi v sovemennoi Anglii, St. Petersburg; German translation Studien zur Theorie und Geschichte der Handelskrisen in England, Fischer, Jena, appeared in1901

Thomas B (1954) Migration and economic growth. Cambridge University Press, Cambridge

Thorp WL (1926) Business annals. NBER, New York

Varga E, Mendelsohn L (1940) New data for V. I. Lenin's Imperialism: the highest stage of capitalism (includes text of Lenin's 1916 pamphlet). International Publishers, New York

Williamson JG (1964) American growth and the balance of payments: a study of the Long Swing, Chapel Hill

de Wolff S (1924) Prosperitäts und Depressionsperioden. In: Jensen O (ed), Der lebendige Marxismus: Festgabe zum 70 Geburtstage von Karl Kautsky, Jena [English translation in Louçã and Reijnders], pp 13-43

Zarnowitz V (1992) Business cycles: theory, history, indicators and forecasting. NBER, Univesity of Chicago 